\title{
ANALIZA TROŠKOVA KVALITETE ODABRANIH GRAĐEVINSKIH RADOVA
}

\author{
QUALITY COST ANALYSIS OF SELECTED \\ CONSTRUCTION WORKS
}

\author{
Ksenija Tijanić ${ }^{*}$, Diana Car-Pušić* , Zlata Dolaček-Alduk ${ }^{* *}$
}

\begin{abstract}
Sažetak
Rad se bavi problematikom troškova kvalitete građevinskih radova. Ovaj se problem, osobito kod nas, do sada nije istraživao u značajnijoj mjeri. U današnje vrijeme, kvaliteta zauzima značajno mjesto u svim djelatnostima pa tako i građevinskoj. Poznato je da zadovoljenje tražene kvalitete predstavlja i jedno od bitnih mjerila uspješnosti realizacije građevinskih projekata. Naravno da postizanje kvalitete iziskuje i trošenje financijskih sredstava. Međutim, uobičajeno je da su ti troškovi sadržani u ukupnim troškovima te se njihovoj kvantifikaciji ne posvećuje posebna pažnja. Za očekivati je da će daljnjim porastom složenosti građevinskih projekata $i$ povećanjem zahtjeva kvalitete problem kvantifikacije ovih troškova dobivati na važnosti. Kao doprinos rješavanju ovog problema provedeno je istraživanje prikupljanjem i analizom podataka o troškovima kvalitete putem anketnog upitnika među zaposlenicima građevinskih tvrtki. Istraživanjem se pokušalo utvrditi uvjetuju li trajanje i troškovi rada i materijala građevinske radne operacije iznos troškova kvalitete. Kriteriji za odabir građevinskih radova bili su učestalost pojavljivanja u projektima visokogradnje te broj radnih operacija od kojih se sastoje. Odabrano je pet radova (izrada oplate temelja, armiranje šipkastom armaturom, ugrađivanje betona C16/20, zidanje zidova opekom, žbukanje zidova), svaki sastavljen od najmanje tri radne operacije. Odabranim radovima određeni su postotni udjeli troškova kvalitete po radnim operacijama, koji su zatim uspoređeni s udjelima vremena i troškova rada i materijala. Vremenski i troškovni udjeli izračunati su pomoću normativa građevinskih radova, dok su udjeli troškova kvalitete procijenjeni na temelju podataka dobivenih anketiranjem. Rezultati su pokazali da iznos troškova kvalitete radnih operacija ispitivanih radova nije nužno proporcionalan trajanju i troškovima
\end{abstract}

\footnotetext{
*Građevinski fakultet u Rijeci, Radmile Matejčić 3, 51000 Rijeka

E-mail: \{ksenija.tijanic, diana.car.pusic\}@gradri.uniri.hr

${ }^{* *}$ Sveučilište Josipa Jurja Strossmayera, Građevinski fakultet Osijek, Vladimira Preloga 3, 31000

Osijek

E-mail: zlatad@gfos.hr
} 
rada i materijala. Drugim riječima, mjerilo postignute kvalitete nije samo vrijeme rada uloženo u njeno dostizanje, kao ni kvaliteta ugrađenih materijala, već i kvaliteta samog rada izvršitelja. Pored toga, kad se radnoj operaciji pristupa s potrebnom pozornošću, smanjuje se i mogućnost pogreške, potreban dodatni rad, a time i dodatni troškovi za kvalitetu.

Ključne riječi: kvaliteta, građevinski rad, radna operacija, vrijeme, troškovi, troškovi kvalitete

\begin{abstract}
The paper deals with the issue of the quality cost of construction works. This problem, especially in our country, has not significantly been explored. At present, quality plays an important role in all activities, including construction. It is well known that meeting the required quality is also one of the essential benchmarks of a successful realization of construction projects. Of course, achieving quality requires spending financial resources. However, it is common that these costs are included in total costs. Thus, not enough attention is paid to their quantification. It is expected that the problem of quantification of these costs will gain more importance with further growth of construction project complexity and quality requirements. As a contribution to solving this problem, a research was conducted through a survey among the employees of construction companies by collecting data on quality costs. The research attempted to determine whether the quality cost depend on time and costs of labor and materials of construction work operation. Criteria for the selection of construction works were the frequency of appearances in building projects and the number of work operations they consisted of. Five works were selected (making formwork for foundation, reinforcing with steel rods, concreting C16/20, wall masonry, plastering of walls), each consisting of at least three work operations. Percentage shares of quality costs are determined in selected works and then compared with shares of time and costs of labor and materials. Time and cost percentage shares were calculated using the norms of construction works while the shares of the quality cost were estimated based on the data obtained by the survey. The results have shown that the amount of quality cost in construction work is not necessarily proportional to the time and cost of the work operation. In other words, the measure of the achieved quality is not merely the time of work invested in its achievement, as well as quality of embedded materials, but the quality of the work of the contractor. Additionally, when a work operation is approached with necessary care, the possibility of error, additional work, and therefore additional quality costs are also reduced.
\end{abstract}

Key words: quality, construction work, work operation, time, cost, quality cost

\title{
1. Uvod
}

Kvaliteta zauzima značajno mjesto u građevinskoj djelatnosti. Poznato je da, uz zadovoljavanje roka i troškova građenja, zadovoljenje tražene 
kvalitete predstavlja jedno od bitnih mjerila uspješnosti realizacije građevinskih projekata. U najopćenitijem smislu, kvaliteta se može definirati kao svojstvo ili osobina koja označava određeni predmet ili pojavu i razlikuje ih od ostalih predmeta ili pojava [1]. Prema normi HRN EN ISO 9000:2015 Sustavi upravljanja kvalitetom - Temeljna načela i terminološki rječnik, kvaliteta se definira kao stupanj u kojem skup svojstvenih značajki zadovoljava zahtjeve [2].

U strukturi ukupnih troškova projekta postoji dio troškova koji se naziva troškovima kvalitete. Za upravljanje ukupnim troškovima projekta potrebno je imati svijest o postojanju troškova kvalitete kao sastavnice ukupnih troškova [3]. Točna i pouzdana procjena troškova građevinskog projekta nije moguća bez duboke analize očekivanih troškova kvalitete [4]. Istraživanja o troškovima kvalitete uglavnom se bave određivanjem udjela troškova kvalitete i ne(kvalitete) u projektima u odnosu na ukupne troškove projekta. Manji je broj istraživanja troškova kvalitete građevinskog rada (aktivnosti) i njegovih radnih operacija.

Cilj ovog rada je doprinijeti rješavanju problema kvantifikacije troškova kvalitete, odnosno utvrditi koliki su troškovi kvalitete određenih građevinskih radova i uvidjeti na koji način se troškovi kvalitete raspoređuju na radne operacije unutar građevinskog rada te u kakvom su odnosu s vremenom i troškovima rada i materijala. Građevinski radovi obrađeni $u$ istraživanju odabrani su na temelju učestalosti pojavljivanja u projektima visokogradnje te broju radnih operacija od kojih se sastoje. Odabrano je pet radova (izrada oplate temelja, armiranje šipkastom armaturom, ugrađivanje betona C16/20, zidanje zidova opekom, žbukanje zidova), od kojih se svaki sastoji od najmanje tri, a najviše četiri radne operacije. Podaci potrebni za istraživanje prikupljeni su u građevinskim tvrtkama na području Primorsko-goranske županije metodom anketnog upitnika.

\section{Pojam troška kvalitete}

Troškovi kvalitete su troškovi koji nastaju pri osiguravanju zadovoljavajuće kvalitete, kao i gubici koji nastaju ukoliko tražena kvaliteta nije postignuta. Mogu se definirati kao troškovi čiji su uzroci pretežno zahtjevi kvalitete, tj. troškovi uzrokovani aktivnostima koje se odnose na sprječavanje pogrešaka, plansko ispitivanje kvalitete te interno i eksterno utvrđene pogreške [5]. Project Management Institute definira trošak kvalitete kao trošak svih nastojanja potrebnih za stjecanje kvalitete proizvoda i usluga, a ta nastojanja uključuju svaki rad potreban prema zahtjevima te preradu [6]. 
Troškovi kvalitete nastaju pri osiguravanju zahtjeva kvalitete, nastaju kao gubici koji se trpe kad zadovoljavajuća kvaliteta nije postignuta te ih ne bi bilo kada bi se svaki posao obavio bez pogreške prvi put [5].

Troškovi kvalitete imaju nekoliko važnih karakteristika koje ih razlikuju od drugih vrsta troškova: u pravilu su prikriveni u okviru drugih vrsta troškova sve dok ih se ne prepozna, evidentira i analizira; sadržani su u kalkulacijama, ali ne kao posebno iskazana stavka kalkulacije; potencijalna su, neiskorištena pričuva; stupanj spoznaje o njima u nekoj organizaciji mjerilo je stupnja svjesnosti o kvaliteti uopće; mogu biti značajni pokazatelj kvalitete, koristan upravi za donošenje ispravnih odluka [7].

Opća podjela troškova kvalitete prikazana je Slikom 1.

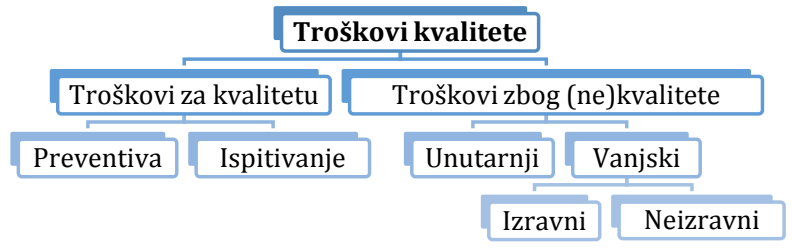

Slika 1. Podjela troškova kvalitete [5]

Troškovi za kvalitetu su ukupan iznos troškova koje je potrebno uložiti u proces poslovanja da bi se osigurao kvalitetan proizvod ili kvalitetno pružanje usluga. Mogu se podijeliti na troškove preventive i troškove ispitivanja. Troškovi preventive su troškovi koji se nameću zbog održavanja troškova propusta i ocjenjivanja na minimum. Troškovi ispitivanja su troškovi koji se javljaju u određivanju stupnja sukladnosti sa zahtjevima kvalitete. Troškove zbog (ne)kvalitete čine svi rashodi koji se javljaju zbog ispravljanja nastalih grešaka. Mogu se podijeliti na troškove unutarnjih gubitaka (manjkavosti) i troškove vanjskih gubitaka (propusta). Troškovi unutarnjih manjkavosti su troškovi kojih ne bi bilo da prije otpreme nisu postojali nedostaci u proizvodu. Troškovi vanjskih propusta su troškovi vezani uz nedostatke koji su ustanovljeni nakon što je proizvod isporučen kupcu [7].

Upravljanje troškovima kvalitete ima za cilj povećanje ulaganja $u$ troškove za kvalitetu, a smanjenje troškove nastale zbog (ne)kvalitete. U teoriji i praksi razlikuju se dva pristupa upravljanja troškovima, tradicionalni i moderni. Tradicionalnim pristupom osiguranja kvalitete otkrivaju se greške na proizvodu koje su već nastale, a rezultiraju troškovima dorade, prerade proizvoda ili škarta proizvoda. Kvaliteta je zadovoljavajuća ako se proizvodi ne vraćaju i ako se ne primaju pritužbe [5]. Suvremeni koncept upravljanja troškovima kvalitete inzistira na 
preventivnom djelovanju, što podrazumijeva da je isplativije istraživati, otkrivati i analizirati uzroke nastajanja grešaka i njihovo eliminiranje, čime troškovi kvalitete mogu biti reducirani [8].

Kako bi se troškovima moglo upravljati, treba ih pratiti i mjeriti. Brojčani podaci su potrebni za postavljanje ciljeva, utvrđivanja razlike između željenog i stvarnog, praćenje tendencija te za donošenje odluka [5].

\section{Istraživanja o troškovima kvalitete}

Prvu detaljniju publikaciju o troškovima kvalitete, „Total Quality Control", izdao je Feigenbaum [9] 1956. godine. U njoj detaljno obrazlaže svoj koncept troškova kvalitete. Uvodi pojam ukupnih troškova kvalitete (engl. total quality costs) i postavlja zahtjev za kontrolom troškova dokazivanjem rezultata primjenom statističkih metoda.

U dosadašnjim istraživanjima o troškovima kvalitete u građevinskim projektima, različiti ulazni kriteriji kao što su troškovi dorade, vanjski troškovi pogrešaka, troškovi nesukladnosti, loše upravljanje materijalom na gradilištu, pretjerana uporaba materijala na gradilištu, troškovi radnog vremena utrošenog na aktivnosti koje ne dodaju vrijednost, rezultirali su i različitim rezultatima [10].

Low i Henson [11] navode da je u publikaciji od strane Odbora za građevinsku industriju (engl. Construction Industry Development Board) pod nazivom Upravljanje kvalitetom gradnje, procijenjeno da prosječni izvođač radova potroši između 5 - 10\% troškova projekta radi pogrešaka u građenju te njihovog ispravljanja. Odbor je zaključio da učinkoviti sustav upravljanja kvalitetom troši oko $0,1-0,5 \%$ ukupnih troškova gradnje i ostvaruje uštedu od najmanje $3 \%$ ukupnih troškova projekta.

U kojoj mjeri troškovi kvalitete mogu smanjiti troškove građenja predstavljeno je u studiji građevinskih projekata u Australiji. Utvrđeno je da se troškovima prevencije troši $1 \%$ više, a troškovi neuspjeha mogu se smanjiti sa $10 \%$ troškova građenja na $2 \%$ [12].

Burati [13] je u svojoj studiji kategorizirao uzroke odstupanja troškova kvalitete u pet područja: projektiranje, građenje, izrada, transport i operabilnost, a svako područje je imalo tri vrste odstupanja: promjena, pogreška i propust. Na temelju podataka iz devet građevinskih projekata, Burati je zaključio da su troškovi odstupanja u fazi projektiranja i fazi građenja iznosili 9,5\% i 2,5\% ukupnog troška.

Lam [14] je u istraživanju iz 1994. godine utvrdio da troškovi kvalitete mogu činiti od 8 - 15\% ukupnih troškova izgradnje građevine. 
Hart [15] tvrdi da su brojne studije pokazale da se više od 25\% troškova može smanjiti u većini izrađenih objekata korištenjem dobrog programa kvalitete. Također, Zambare i Dhawale [16] tvrde da se troškovi kvalitete mogu reducirati za trećinu, ako se u projektima primjenjuje efikasan sustav upravljanja kvalitetom.

Do sada je razvijeno nekoliko sustava za određivanje troškova kvalitete kao što su: Quality Performance Management System (QPMS), Quality Performance Tracking System (QPTS), Quality Cost Matrix (QCM), Project Management Quality Cost System (PROMQACS).

Ledbetter [17], koji je predložio QPMS, mjerio je troškove aktivnosti kontrole kvalitete i prerade. Nedostatak je bio što se QPMS može primijeniti samo za procjenu troškova rada. Okvirom QPMS-a Ledbetter je analizirao podatke dvanaest građevinskih projekata i utvrdio da je trošak kvalitete vezane za rad do 11,2\% ukupnih troškova rada. Patterson i Ledbetter [18] također koriste QPMS za praćenje troškova kvalitete po aktivnosti na četiri projekta te su utvrdili da su troškovi kvalitete $25 \%$ troškova projekta. Iako je ovaj sustav bio jednostavan i fleksibilan, nije razmatrao učinak neuspjeha na vremenski povezane troškove. Pored toga, sustav nije identificirao specifične uzroke neuspjeha.

QPTS, ažurirana verzija QPMS-a razvijena je za karakteriziranje troškova kvalitete. Definiranjem kvalitete kao „usklađenosti sa zahtjevima", trošak kvalitete postaje mjerljiv. QPTS se sastoji od dva glavna dijela, troškova napora za upravljanje kvalitetom i troška ispravljanja odstupanja [4].

Zambare i Dhawale [16] navode da je Abdul-Rahman prepoznao određene nedostatke QPTS sustava te razvio QCM, koji je uzimao u obzir učinak neuspjeha na vrijeme, osobito trošak ubrzavanja rada i specifičnih uzroka nesukladnosti.

Love [19] je osmislio sustav PROMQASC. Sustav PROMQACS je konstruiran na temelju standardne strukture troškova kvalitete i koristan je u prikupljanju srodnih podataka i dijeljenju podataka sa sudionicima, no ne postoji posebna metoda prikupljanja kvalitetnih podataka o građevinskim projektima.

Low i Henson [11] u svojoj publikaciji tvrde da nije dovoljno znati značenje troškova kvalitete, već ih, da bi podaci o troškovima bili korisni, treba prikupljati i mjeriti. Predložili su sustav za određivanje troškova kvalitete na gradilištu. Njihov sustav troškova je matrica dokumentacije, gdje se troškovi kvalitete izražavaju kao troškovi prevencije, procjene i neuspjeha. Predloženi troškovni model sastoji se od sedam komponenti: kod troška, obuhvaćeni posao, uzroci, problematična područja, potrošeno 
vrijeme, nastali troškovi i bilješke na gradilištu. Kao najveći problem ovakvog sustava istakli su dugi vremenski period za prikupljanje potrebnih podataka.

Istraživanje provedeno u hrvatskim tvrtkama, certificiranim po modelu ISO 9001 iz 1999. godine, pokazalo je da je udio troškova kvalitete u ispitanim certificiranim tvrtkama u prosjeku 7,8\% ukupnih troškova cijelog projekta. Tvrtke koje posjeduju certifikat ISO 9001 dokazuju uspješno implementiran sustav upravljanja kvalitetom u svojoj organizaciji. U ispitanim tvrtkama troškovi za kvalitetu sudjeluju sa 60\%, a troškovi zbog loše kvalitete sa 40\% u ukupnim troškovima kvalitete [7].

Troškove kvalitete u građevinskim projektima u Republici Hrvatskoj obradila je Dolaček-Alduk [10] te je utvrdila da prosječni ukupni troškovi kvalitete za bazu od osamnaest projekata promatranih u istraživanju iznose $1,83 \%$ ugovorene vrijednosti projekta. Troškovi za kvalitetu iznose prosječno $0,93 \%$, nešto više od $50 \%$ ukupnih troškova kvalitete. Troškovi zbog loše kvalitete radova iznose prosječno $0,90 \%$, nešto manje od $50 \%$ ukupnih troškova kvalitete. U okviru istraživanja predstavljen je i model upravljanja troškovima kvalitete koji podrazumijeva: identifikaciju i praćenje troškova kvalitete, reviziju aktivnosti u projektima i pregled koji provodi uprava, analizu troškova i koristi te implementaciju poboljšanja.

\section{Provedeno istraživanje}

U provedenom istraživanju, na pet građevinskih radova ispituje se udio troškova kvalitete za svaku pojedinu radnu operaciju unutar građevinskog rada u odnosu na vrijeme i troškove operacije, odnosno ispituje se slijede li troškovi kvalitete razdiobu troškova i vremena radne operacije. Postavljaju se sljedeća pitanja: "Jesu li kod operacije koja iziskuje najviše vremena za izvođenje i ima najveće troškove rada i materijala troškovi kvalitete ujedno i najveći?“ te obrnuto, „Jesu li kod operacije koja iziskuje najmanje vremena i troškova troškovi kvalitete najmanji?"

U Tablici 1 prikazani su odabrani građevinski radovi s pripadajućim radnim operacijama. 
Tablica 1. Građevinski radovi i radne operacije

\begin{tabular}{|c|c|c|}
\hline Građevinski rad & $\begin{array}{l}\text { Oznaka } \\
\text { radne } \\
\text { operacije }\end{array}$ & Radna operacija \\
\hline \multirow{4}{*}{$\begin{array}{l}\text { Izrada dvostrane oplate temelja od } \\
\text { daske debljine } 24 \mathrm{~mm}\end{array}$} & 1.a. & Izrada \\
\hline & 1.b. & Montaža \\
\hline & 1.c. & Demontaža \\
\hline & 1.d. & Čišćenje i vađenje čavala \\
\hline \multirow{4}{*}{$\begin{array}{l}\text { Ručno sječenje, ispravljanje, savijanje, } \\
\text { postavljanje i povezivanje armature } \\
\emptyset 12 \mathrm{~mm} \text {, čelik B500B }\end{array}$} & 2.a. & Sječenje i ispravljanje \\
\hline & 2.b. & Savijanje \\
\hline & 2.c. & Postavljanje i vezivanje \\
\hline & 2.d. & Prijenos \\
\hline \multirow{3}{*}{$\begin{array}{l}\text { Ručno ugrađivanje betona klase C } \\
\text { 16/20 u armirane konstrukcije } \\
\text { srednjih presjeka, beton se spravlja na } \\
\text { gradilištu }\end{array}$} & 3.a. & Spravljanje \\
\hline & 3.b. & Ugrađivanje \\
\hline & 3.c. & Prijenos \\
\hline \multirow{4}{*}{$\begin{array}{l}\text { Zidanje zidova punom opekom u } \\
\text { produžnom cementnom mortu } \\
\text { omjera } 1: 2: 6\end{array}$} & 4.a. & Spravljanje morta \\
\hline & 4.b. & Zidanje \\
\hline & 4.c. & Prijenos morta \\
\hline & 4.d. & Prijenos opeke \\
\hline \multirow{4}{*}{$\begin{array}{l}\text { Žbukanje zidova od opeke u } \\
\text { produžnom cementnom mortu } \\
\text { omjera 1:2:6 }\end{array}$} & 5.a. & Spravljanje morta \\
\hline & 5.b. & Grubo žbukanje \\
\hline & 5.c. & Fino žbukanje \\
\hline & 5.d. & Prijenos morta \\
\hline
\end{tabular}

Radovi i pripadajuće operacije, uključivši i navedeni slijed, preuzeti su iz knjige normativa građevinskih radova [20]. Pomoću normativa vremena radnika i materijala određeni su vremenski i troškovni udjeli koje radne operacije imaju pri proizvodnji jedinice proizvoda. Potrebne cijene radnika i materijala preuzete su iz Biltena Standardne kalkulacije, XII 2017 [21]. Obračunski faktor korišten $\mathrm{u}$ analizi cijena uzet je kao konstanta, $\mathrm{u}$ vrijednosti 3, koja je određena kao prosječna vrijednost.

Određivanje troškova kvalitete radnih operacija mnogo je kompleksniji posao koji bi u stvarnosti zahtijevao izradu sustava dugotrajnog praćenja i mjerenja pojedinih radova. $\mathrm{Za}$ potrebe ovog istraživanja podaci su prikupljeni putem anketnog upitnika koji su dostavljeni ispitanicima, zaposlenicima građevinskih izvođačkih tvrtki, direktno ili indirektno uključenih u proces građenja.

Anketni upitnik je podijeljen u dva dijela. U prvom dijelu sadrži opća pitanja o radnom iskustvu ispitanika, obrazovanju, radnom mjestu unutar poduzeća te upoznatosti s troškovima kvalitete i njihovom strukturom. Uz pretpostavku da određeni dio ispitanika neće biti upoznat s pojmom i 
strukturom troškova kvalitete, u upitniku je dano objašnjenje tih troškova, njihovo značenje i struktura. Ispitanici su upoznati s preventivnim troškovima, troškovima ispitivanja te unutarnjim i vanjskim troškovima koji nastaju zbog (ne)kvalitete.

U drugom dijelu upitnika od ispitanika se traži da na temelju vlastitog znanja i iskustva iz struke ocijene učešće, tj. postotak troška kvalitete po pojedinim radnim operacijama u ukupnom trošku kvalitete građevinskog rada. Ispitanicima su predočeni građevinski radovi koji se ispituju, razloženi na radne operacije te se od njih traži da svakoj radnoj operaciji pridruže određeni postotak koje po njihovom mišljenju ta operacija ima u ukupnom trošku kvalitete stavke.

\section{Rezultati istraživanja}

Istraživanjem je obuhvaćeno 35 zaposlenika građevinskih poduzeća, uglavnom s područja Primorsko-goranske županije, čija su gradilišta na istom tom području.

Ispitanici imaju različita radna mjesta unutar poduzeća, kao što su: voditelj gradilišta, poslovođa, direktor, voditelj radne grupe, nadzorni inženjer i izrađivač ponuda. Slika 2 prikazuje strukturu radnog iskustva ispitanika (a), razinu obrazovanja ispitanika (b) te strukturu ispitanika prema upoznatosti s pojmom troška kvalitete (c).

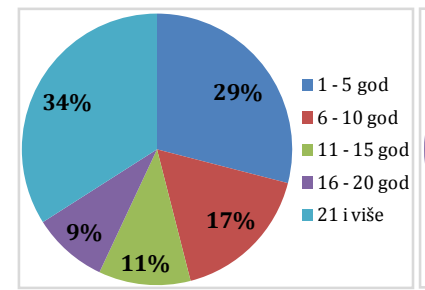

a)

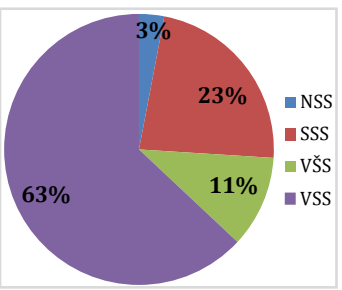

b)

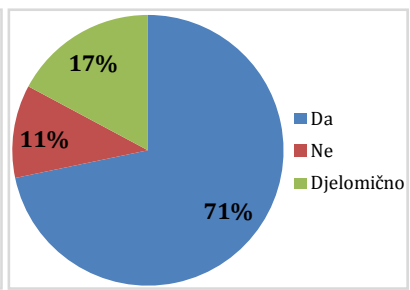

c)

Slika 2. Struktura: a) radno iskustvo ispitanika, b) razina obrazovanja ispitanika, c) upoznatost ispitanika s pojmom troška kvalitete

Struktura troškova kvalitete poznata je 26-orici ispitanika (74\%), a ostalih 9 ispitanika (26\%) nije upoznato sa strukturom troškova kvalitete.

Iako su ispitanicima prije ispunjavanja ankete dana potrebna prethodna objašnjenja, treba imati na umu činjenicu da $26 \%$ ispitanika nije bilo upoznato sa strukturom troškova kvalitete. Posljedično, pri analizi dobivenih rezultata i donošenju zaključaka treba uzeti u obzir da četvrtini svih ispitanika struktura troškova kvalitete prethodno nije bila poznata. Iako su im dane potrebne informacije, od utjecaja je i razumijevanje i 
usvojeno znanje o problemu koje je vjerojatno manje nego kod ispitanika koji su od ranije upoznati s problemom ili čak imaju određena praktična iskustva. Također, budući da se istraživanje odnosi samo na Primorskogoransku županiju i pojedine građevinske tvrtke iz tog područja, potrebno je uzeti u obzir da na razini Republike Hrvatske (a i šire) u svim regijama, pa tako i građevinskim tvrtkama, ne vladaju isti gospodarski uvjeti te se u različitim građevinskim tvrtkama problematika kvalitete tretira različito, o čemu posljedično zavise i pripadajući troškovi. Stoga rezultate ovog istraživanja treba tumačiti s obzirom na navedena ograničenja i ne donositi opće zaključke. No, uz veći broj ispitanika sa šireg područja Republike Hrvatske, a uz primjenu predloženog koncepta, dobili bi se šire primjenjivi, općenitiji zaključci.

\subsection{Odnos "vrijeme-troškovi-troškovi kvalitete" radnih operacija unutar građevinskih radova}

$\mathrm{Na}$ temelju odgovora koje su ispitanici dali u anketnom upitniku određeni su postotni udjeli troškova kvalitete radnih operacija za svaki promatrani građevinski rad. Rezultati su prikazani u obliku kumulativnih Skrivulja na Slici 3. Slika prikazuje udjele sva tri promatrana parametra građevinskog rada, dakle vrijeme, troškove i troškove kvalitete.

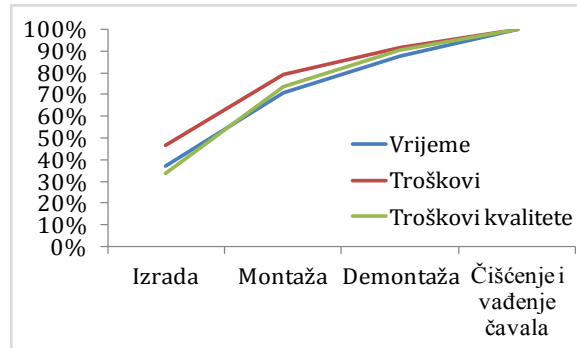

a)

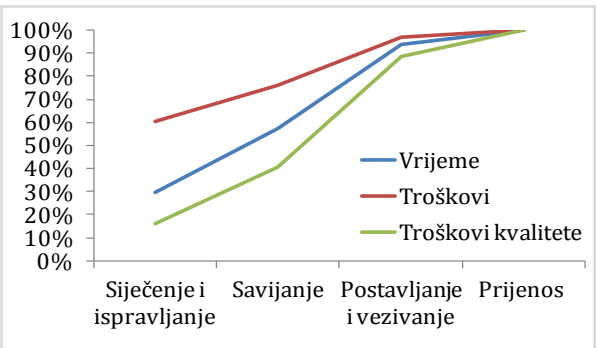

b)

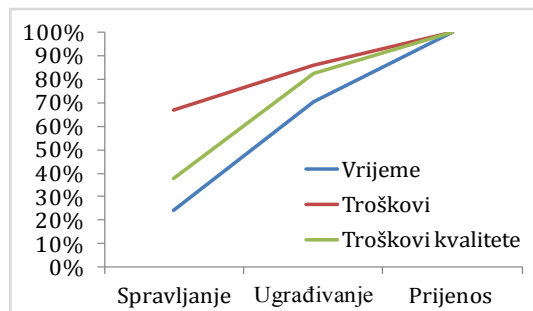

c)

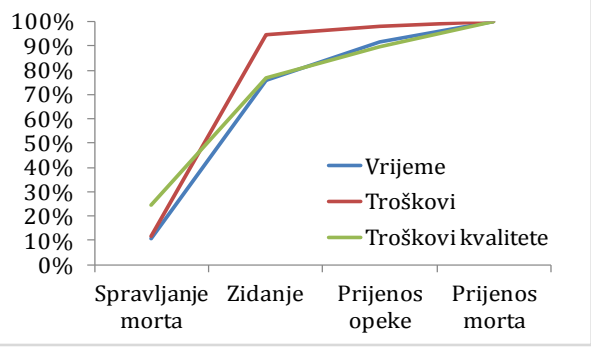

d) 


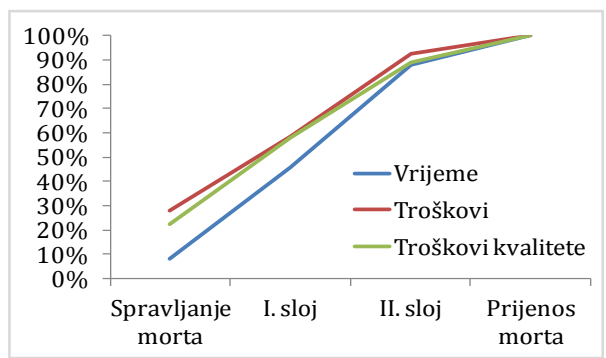

e)

Slika 3. Udjeli parametara radnih operacija: a) izrada oplate, b) armiranje, c) betoniranje, d) zidanje zidova, e) žbukanje zidova

Iz priloženih grafova vidljivo je da se raspodjela sva tri parametra pojedinog građevinskog rada vrši po sličnom obliku, s pripadajućim vrijednostima, slijedeći oblik S-krivulje. Kod svih radova S-krivulja troškova (rada i materijala) ima najveće postotne vrijednosti. Krivulja troškova kvalitete nalazi se između krivulja vremena i troškova, osim kod radova armiranja. Kod radova izrade oplate vidljiv je trend prirasta troškova kvalitete u vremenu koji približno prati trend ukupnog rasta troškova. To je ujedno i trend prirasta troškova po radnim operacijama. Kod armiračkih radova prirast troškova kvalitete je sporiji. Manji je prirast u početnim operacijama (sječenju i ispravljanju) te brže raste u narednim operacijama. Trend prirasta ukazuje i na učešće ovih troškova u ukupnoj strukturi. Kod betonskih radova tijek S-krivulje troškova kvalitete ukazuje na značajnu prevagu troškova učešća prijenosa i ugrađivanja u odnosu na spravljanje betona. Slična situacija je kod zidarskih radova, s prevagom učešća prijenosa morta i opeke te zidanja u odnosu na spravljanje morta. Kod žbukanja zidova, slična je situacija kao kod tesarskih radova kad je u pitanju tijek S-krivulje troškova kvalitete, a u strukturi troškova s prevagom izvedbe prijenosa morta i sloja fine žbuke u odnosu na spravljanje morta, špric i grubu žbuku.

U Tablici 2 prikazane su normirane vrijednosti udjela po promatranim parametrima i radnim operacijama. U tablici su crvenom ( $\square$ ) bojom označeni najveći udjeli promatranih parametara za svaku radnu operaciju, dok su plavom ( ) označeni najmanji udjeli. 
Tablica 2. Odnos parametara radnih operacija za promatrane građevinske radove

\begin{tabular}{|c|c|c|c|c|}
\hline Građevinski rad & $\begin{array}{l}\text { Oznaka radne } \\
\text { operacije }\end{array}$ & Vrijeme & Troškovi & $\begin{array}{l}\text { Troškovi } \\
\text { kvalitete }\end{array}$ \\
\hline \multirow{4}{*}{$\begin{array}{l}\text { Izrada dvostrane oplate } \\
\text { temelja od daske } \\
\text { debljine } 24 \mathrm{~mm}\end{array}$} & 1.a. & 1,00 & 1,00 & 0,84 \\
\hline & 1.b. & 0,90 & 0,70 & 1,00 \\
\hline & 1.c. & 0,45 & 0,26 & 0,43 \\
\hline & 1.d. & 0,33 & 0,18 & 0,24 \\
\hline \multirow{4}{*}{$\begin{array}{l}\text { Ručno sječenje, } \\
\text { ispravljanje, savijanje, } \\
\text { postavljanje i } \\
\text { povezivanje armature } \\
\emptyset 12 \mathrm{~mm} \text {, čelik B500B }\end{array}$} & 2.a. & 0,82 & 1,00 & 0,33 \\
\hline & 2.b. & 0,76 & 0,26 & 0,51 \\
\hline & 2.c. & 1,00 & 0,34 & 1,00 \\
\hline & 2.d. & 0,18 & 0,05 & 0,23 \\
\hline \multirow{3}{*}{$\begin{array}{l}\text { Ručno ugrađivanje } \\
\text { betona klase C } 16 / 20 \mathrm{u} \\
\text { armirane konstrukcije } \\
\text { srednjih presjeka, beton } \\
\text { se spravlja na gradilištu }\end{array}$} & 3.a. & 0,52 & 1,00 & 0,85 \\
\hline & 3.b. & 1,00 & 0,28 & 1,00 \\
\hline & 3.c. & 0,84 & 0,21 & 0,39 \\
\hline \multirow{4}{*}{$\begin{array}{l}\text { Zidanje zidova punom } \\
\text { opekom u produžnom } \\
\text { cementnom mortu } \\
\text { omjera } 1: 2: 6\end{array}$} & 4.a. & 0,16 & 0,14 & 0,47 \\
\hline & 4.b. & 1,00 & 1,00 & 1,00 \\
\hline & 4.c. & 0,25 & 0,05 & 0,25 \\
\hline & 4.d. & 0,12 & 0,02 & 0,20 \\
\hline \multirow{4}{*}{$\begin{array}{l}\text { Žbukanje zidova od } \\
\text { opeke u produžnom } \\
\text { cementnom mortu } \\
\text { omjera } 1: 2: 6\end{array}$} & 5.a. & 0,19 & 0,81 & 0,64 \\
\hline & 5.b. & 0,89 & 0,89 & 1,00 \\
\hline & 5.c. & 1,00 & 1,00 & 0,89 \\
\hline & 5.d. & 0,29 & 0,21 & 0,31 \\
\hline
\end{tabular}

Iz rezultata je vidljivo da samo kod rada „zidanje zidova opekom“ ista radna operacija ima najveće udjele vremena, troškova i troškova kvalitete. Dakle, za operacije koje troše najviše resursa ne mora značiti da imaju najveće troškove kvalitete. Što se tiče najmanjih udjela, radovi „izrada dvostrane oplate, armiranje šipkastom armaturom i zidanje zidova opekom" imaju najmanje udjele sva tri parametra unutar jedne radne operacije. Kod svih promatranih građevinskih radova operacija koja troši najmanje novca za rad i materijal ima i najmanje troškove kvalitete.

Iz svega navedenog vidljivo je da ne postoji jednoznačna veza između potrebnih resursa i troškova kvalitete koja bi vrijedila za sve promatrane građevinske radove u cjelini, kao ni pojedinačne radne operacije. 


\section{Zaključak}

Građevinska industrija jedna je od temeljnih industrija svake zemlje i ima bitnu ulogu u njenom razvoju. Razvoj građevinske industrije ovisi o nizu čimbenika, a na taj razvoj utjecaj ima i kvaliteta građevinskih projekata. Općenito, kvaliteta je jedan od bitnih čimbenika za uspjeh građevinskog projekta. Bitan parameter kvalitete njezini su troškovi. Troškovi kvalitete predstavljaju sve one izdatke potrebne za ispravljanje nastalih grešaka, kao i izdatke za sprječavanje njihova nastanka. Drugim riječima, troškovi kvalitete jesu spoj troškova za kvalitetu i troškova zbog nekvalitete. Troškovi kvalitete prikriveni su u okviru drugih vrsta troškova sve dok ih se ne prepozna, evidentira i analizira. Kao i ostale vrste troškova, važno ih je pravilno planirati, pratiti i kontrolirati.

Radom je predstavljeno istraživanje u kojem se ispituju troškovi kvalitete na pet odabranih građevinskih radova. Kao rezultat istraživanja zaključeno je da ne postoji pravilo po kojem se troškovi kvalitete odabranih građevinskih radova raspoređuju na pojedinačne, sastavne radne operacije, odnosno ne ovise o udjelima vremena i troškova rada i materijala. Mjerilo postignute kvalitete nije samo vrijeme rada uloženo u njeno dostizanje, kao ni kvaliteta ugrađenih materijala, nego i kvaliteta samog rada izvođača radova. Uz to, kad se radnoj operaciji pristupa s potrebnom pozornošću, smanjuje se i mogućnost pogreške, potreban dodatni rad, a time i dodatni troškovi za kvalitetu. Svaka radna operacija treba zadovoljiti sve potrebne zahtjeve kvalitete propisane zakonom, bez obzira koliko se vremena ili financijskih sredstava na nju troši. Nepoštivanje zahtjeva kvalitete radnih operacija građevinskog rada svakako će imati negativan utjecaj na građevinu, čak i ako se ta operacija čini vremenski i troškovno manje bitnom.

Zaključno, važno je istaknuti da kvaliteta i troškovi nisu uvijek proporcionalni, odnosno da veći trošak radova neće uvijek rezultirati višom kvalitetom, ali će nepoštivanje načela kvalitete u izvedbi građevine vrlo vjerojatno rezultirati dodatnim troškovima $u$ fazi implementacije i eksploatacije građevine.

\section{Literatura}

[1] Funda, D. (2010) Sustavi upravljanja kvalitetom u logistici, Tehnički glasnik, 4 (1), 94-98.

[2] HRN EN ISO 9000:2015 Sustavi upravljanja kvalitetom - Temeljna načela i terminološki rječnik. 
[3] Vinšalek Stipić, V.; Bošnjak, M. (2015) Praćenje troškova kvalitete $u$ poslovnim organizacijama, Praktični menadžment - stručni časopis za teoriju i praksu menadžmenta, 6 (1), 137-140.

[4] Tawfek, H. i ostali (2012) Assessment of the Expected Cost of Quality (COQ) in Construction Projects in Egypt Using Artificial Neural Network Model, HBRC Journal, 8, 132-143.

[5] Drljača, M. (2004) Mala enciklopedija kvalitete $V$ - dio - Troškovi kvalitete, Zagreb: Oscar.

[6] PMI (2000) A Guide to the Project Management Body of Knowledge (PMBOK Guide).

[7] Lazibat, T., Matić, B. (2000) Troškovi kvalitete kao čimbenik povećanja konkurentnosti na domaćem i svjetskom tržištu, Ekonomski pregled, 51 (1112), 1334-1351.

[8] Šunjić-Beus, M.; Martinović, D. (2007) Upravljanje troškovima kvaliteta: Brdarević, S. Naučno-stručni skup sa međunarodnim učešćem "KVALITET 2007", Neum, Bosna i Herzegovina, 465-470.

[9] Feigenbaum, A. (1991) Total Quality Control, 3rd Edition, McGraw-Hill, New York.

[10] Dolaček-Alduk, Z. i ostali (2009) Model upravljanja troškovima kvalitete u građevinskim projektima, Građevinar, 61 (2), 147-156.

[11] Low, S. P.; Henson K. C. Y. (1998) A Construction Quality Costs Quantifying System for the Building Industry, International Journal of Quality \& Reliability Management, 15 (3), 329-349.

[12] Roberts, R. (1991) Quality Does Not Cost - It Pays, Australian Construction Law Report, 10 (4), 137-44.

[13] Burati, J. L. i ostali (1992) Causes of Quality Deviations in Design and Construction, Journal of Construction Engineering and Management, 118 (1), 34-49.

[14] Lam, S. W. i ostali (1994) ISO 9000 in Construction, McGraw-Hill, Singapur.

[15] Hart, R.D. (1994) Quality Handbook for the Architectural, Engineering and Construction Community, Quality Press, Milwaukee, WI.

[16] Zambare, P.; Dhawale, A. (2017) Project Managament Information System in Construction Industry, International Journal of Engineering Sciences \& research Technology, 6 (7), 54-60.

[17] Ledbetter, W. B. (1994) Quality Performance on Successful Project, Journal of Construction Engineering and Management, 120 (1), 34-46.

[18] Patterson, L.; Ledbetter, W. B. (1989) The Cost of Quality: A Management Tool, u: R.J. Bard (Ed.), Excellence in the Construction Project, American Society of Civil Engineers, 100-105.

[19] Love, P. E. D. i ostali (2003) A Project Management Quality Cost Information System for the Construction Industry, Information and Management, 40, 649-661. 
[20] Građevinska knjiga (1985) Normativi i standardi rada u građevinarstvu, Visokogradnja, Knjiga 1, Knjiga 2, Beograd.

[21] Institut IGH (2017) Bilten, Standardna kalkulacija radova u visokogradnji, XII 2017, Zagreb. 